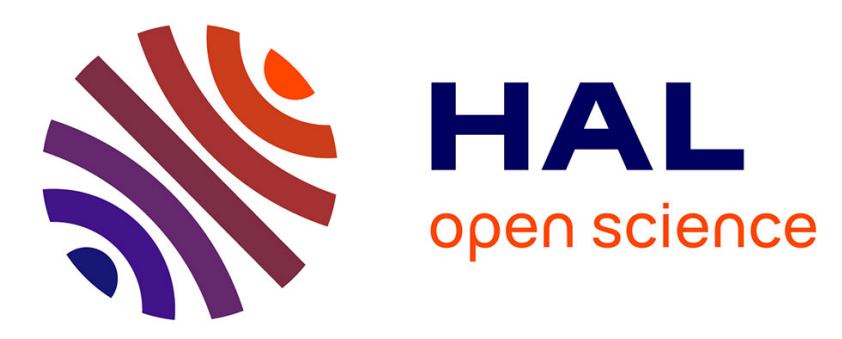

\title{
Natural hydraulic fractures in the Wessex Basin, SW England: widespread distribution, composition and history
}

\author{
Alain Zanella, Peter Robert Cobbold, Tony Boassen
}

\section{- To cite this version:}

Alain Zanella, Peter Robert Cobbold, Tony Boassen. Natural hydraulic fractures in the Wessex Basin, SW England: widespread distribution, composition and history. Marine and Petroleum Geology, 2015, 68 (Part A), pp.438-448. 10.1016/j.marpetgeo.2015.09.005 . insu-01200780

HAL Id: insu-01200780

https://hal-insu.archives-ouvertes.fr/insu-01200780

Submitted on 18 Sep 2015

HAL is a multi-disciplinary open access archive for the deposit and dissemination of scientific research documents, whether they are published or not. The documents may come from teaching and research institutions in France or abroad, or from public or private research centers.
L'archive ouverte pluridisciplinaire HAL, est destinée au dépôt et à la diffusion de documents scientifiques de niveau recherche, publiés ou non, émanant des établissements d'enseignement et de recherche français ou étrangers, des laboratoires publics ou privés. 


\title{
Natural hydraulic fractures in the Wessex Basin, SW England: widespread distribution, composition and history
}

\author{
A. Zanella ${ }^{1,2}$, P.R. Cobbold ${ }^{1}$ and T. Boassen ${ }^{4}$ \\ ${ }^{1}$ Géosciences-Rennes (UMR-6118), CNRS et Université de Rennes 1, Campus de Beaulieu, \\ 35042 Rennes Cedex, France \\ ${ }^{2}$ L.P.G., CNRS UMR 6112, Université du Maine, Faculté des Sciences, 72085 Le Mans \\ Cedex 9, France \\ ${ }^{4}$ Statoil ASA Research Centre, NO-7005 Trondheim, Norway \\ *Corresponding author, e-mail: alain.zanella@univ-lemans.fr
}

\begin{abstract}
Bedding-parallel veins of fibrous calcite ('beef') are historical in the Wessex Basin. The veins are common in Mesozoic mudstones and shales, especially of Liassic to MidCretaceous ages. Cone-in-cone structures, which consist of multiple nested cones, are also well developed within the 'beef'. To investigate the distribution and the context of formation of 'beef' in the basin, we have made several field studies and analysed numerous samples. The veins are widespread vertically and horizontally in the sedimentary sequence, but they are especially common near or within potential source rocks for petroleum or near major tectonic faults. The internal structures of some 'beef' veins have revealed that they formed during Late Cretaceous to Tertiary compressional inversion of the basin. The typical composition for 'beef' is of calcite, with some pyrite and fragments of shale. However, inclusions or patches of hydrocarbons (liquid or solid) occur within calcite crystals or between fibres, respectively. According to some previous studies, as well as ours, 'beef' veins of the Wessex Basin represent natural hydraulic fractures, which formed as a result of fluid overpressure. This may have resulted in part from chemical compaction of petroleum source rocks, during Late Cretaceous to Tertiary times. Indeed, source rocks at outcrop in the Wessex Basin could be more mature than previously thought and the 'beef' veins may be good markers of maturation.
\end{abstract}

Keywords: Wessex Basin, 'beef', overpressure development, organic matter 


\section{Introduction}

Bedding-parallel veins of fibrous calcite ('beef') are common worldwide in sedimentary basins, especially in shales or mudstones (see the recent reviews by Cobbold et al., 2013, and Gale et al., 2014). Buckland and De la Beche (1835) may have been the first geologists to use the term 'beef' for calcite veins in the Wessex Basin, SW England. Workmen there had already adopted the term, because of the resemblance between the fibrous veins and animal muscle (Fig. 1A). Some veins of 'beef' also contain 'cone-in-cone' structures, which consist of multiple nested cones of fibres (Fig. 1B). These internal structures were especially well described by Denaeyer, mostly in France, but also in England (e.g. Denaeyer, 1943, 1947). Hereafter we will use the term 'beef' for all bedding-parallel veins of fibrous calcite and only mention 'cone-in-cone' as an internal structure of these. In the Wessex Basin, Mesozoic strata are well exposed along the coast (Fig. 2). Over the last two centuries, many authors have described 'beef' in this basin (e.g. Buckland and De la Beche, 1835; Lang, 1914, Lang et al., 1923; Howitt, 1964; Palmer, 2014). This is especially true near the localities of Lyme Regis and Charmouth, Devon, where Lang et al. (1923) named a sequence of Liassic age (now a Member of the Charmouth Mudstone Formation) the 'Shales-with-Beef'.

More generally, during the last centuries, numerous scientists have suggested the mechanisms of formation of fibrous veins, distinguishing between (1) fracturing and (2) fibre growth within the fractures. Fibres may grow by a crack-seal mechanism (Ramsay 1980) or in a continuous manner (Taber, 1918; Durney and Ramsay, 1973; Means and Li, 2001). Tarr (1933) and Bons and Jessel (1997) argued that fibrous minerals grow under the effects of concentration gradients. Indeed, fibrous crystals grow by precipitation from supersaturated aqueous solutions, under various conditions of temperature and pressure.

For the generation and opening of fractures, some authors have privileged internal agents, such as force of crystallization (Keulen et al., 2001; Gratier et al., 2012). It seems, however, from theoretical and experimental data (Taber, 1918; Means and Li, 2001; Keulen et al., 2001), that this force is not always great enough to open a fracture. There are however several potential external agents, especially tectonic stress and pore fluid pressure. For developing horizontal fractures, Gustavson et al. (1994) advocated dissolution at depth, whereas Shearman et al. (1972) and Stoneley (1983) highlighted the role of fluid overpressure. Several authors have argued that the tensile strength of the rock should be smallest in a direction perpendicular to bedding (Cosgrove, 1995, 2001; Lash and Engelder, 2005) and certainly this should help. However, Cobbold and Rodrigues (2007) argued and 
demonstrated experimentally that an upward-decreasing overpressure gradient leads to the development of vertical seepage forces and therefore may create horizontal fractures. Indeed, several authors (Lang et al., 1923; Rodrigues et al., 2009; Cobbold et al., 2013; Zanella et al., 2015) have described evidence for progressive antitaxial growth of calcite, during the opening of 'beef' veins, in both the Wessex Basin and the Neuquén Basin (Argentina). Thus Lang et al. (1923, page 53) described fossil prints of ammonites, on both sides of 'beef' veins in the Wessex Basin, demonstrating that opening occurred perpendicular to bedding. More specifically, Rodrigues et al. (2009, their Fig. 7) showed clear photographs of 'beef" veins in the Neuquén Basin, in which calcite fibres link (1) original ammonite shells at the centres of the veins with (2) their prints at the outer edges, showing that the veins had opened antitaxially and somewhat obliquely.

One mechanism for obtaining fluid overpressure is by load transfer during chemical compaction (Swarbrick et al., 2002; Zanella et al., 2014a). If part of the solid framework collapses (by transformation from solid to liquid), the weight of the overburden then transfers to the pore fluid. This leads to natural hydraulic fracturing, if the total fluid pressure becomes greater than the sum of the lithostatic pressure and the tensile strength of the rock.

Indeed, in many sedimentary basins worldwide, calcite 'beef' occurs in or near potential source rocks for petroleum (Cobbold et al., 2013). This is particularly true in basins where the source rock is or has been mature. In this context, several authors have described liquid oil or bitumen as inclusions within fibrous veins of calcite (Stoneley, 1983; Dobes et al., 1999; Parnell et al., 2000) or specifically within calcite 'beef' (Rodrigues et al., 2009; Cobbold et al., 2013, 2015; Zanella et al., 2014b, 2015). Crystallization of 'beef', maturation of organic matter and migration of hydrocarbons may thus be synchronous phenomena. In turn, 'beef' veins may contain physical and chemical information that is relevant to our understanding of hydrocarbon generation in sedimentary basins (see, for example, Rodrigues et al., 2009).

In such a context, we have revisited and sampled numerous 'beef' veins and host rocks throughout the Wessex Basin, so as to study the distribution and the timing of formation of 'beef' veins.

\section{Geological context}

\subsection{Stratigraphy and tectonics of the Wessex Basin}


The Wessex Basin lies along the coast of South-West England (Fig. 2). It contains a Permian to Oligocene sedimentary sequence, which post-dates the Devonian-Carboniferous sequence of the Proto-Tethys Ocean (Glennie and Underhill, 1998; Fig. 3). The structural development of the basin started during the Late Carboniferous to Early Permian climax of the Variscan orogeny (Chadwick et al., 1983). Deposition of sediment occurred during Permo-Triassic rifting and then continued during the Mesozoic period (Fig. 4). Thus the sedimentary fill of the Wessex Basin consists of three megasequences (Permian to Lower Cretaceous; Upper Cretaceous; Tertiary; Fig. 3) with intervening erosional unconformities (Hawkes et al., 1998) (Fig. 4B). The corresponding sedimentary environments were, successively, (1) continental, (2) deepshore marine with mud-dominated sediments due to a widespread marine transgression and (3) near-shore to non-marine. The thickness of the sedimentary fill is very heterogeneous. Due to rifting, differential burial or Tertiary tectonic inversion and erosion, the stratigraphic thickness is variable from locality to locality, in particular near major tectonic faults or structural elements (Bray et al., 1998) (Fig. 4). It can be seen therefore that the history of the Wessex Basin has been quite complex, especially during the Cenozoic inversion, uplift and erosion.

Major normal faults, E-W trending, developed during Late Palaeozoic to Mesozoic times and were reactivated in compression during Late Cretaceous to Tertiary times (e.g. Stoneley, 1982; Lake and Karner, 1987; Chadwick, 1993; Underhill \& Paterson, 1998; Underhill \& Stoneley, 1998). The largest of these structures is the Purbeck - Isle of Wight fault system (Figs. $2 \& 4$ ). This accommodated much of the compressional deformation during the Late Cretaceous and Tertiary periods, producing major monoclinal flexures. On the southern side of the fault, the hanging wall has undergone a regional uplift of about $1.5 \mathrm{~km}$ (Bray et al. 1998). As a result of such Late Cretaceous to Cenozoic inversion, the sedimentary fill of the Wessex Basin is well exposed along the coasts of east Devon, Dorset and Hampshire and on the Isle of Wight. Thus several generations of geologists have studied this area, which is now part of a World Heritage Site.

Another result of mainly Tertiary inversion is the anticline in the Vale of Wardour, which is well inland (Fig. 2). There, Late Jurassic strata of the Purbeck Beds crop out along the valley and contain calcite 'beef' (Brodie, 1854; Andrews, 1881; Andrews and JukesBrown, 1894).

\subsection{Petroleum geology and fluids of the Wessex Basin}


The petroleum geology of the Wessex Basin involves mainly Mesozoic strata (Fig. 3). The first exploration well (Poxwell-1) was drilled in 1937 (Buchanan, 1998). Another historical discovery (in the 1950s) was the Kimmeridge oilfield, on the Dorset coast, which is still in production (Buchanan, 1998). Onshore, the major oilfield of the Wessex Basin is Wytch Farm on the Isle of Purbeck, which entered production in the 1970s (Fig. 2). The petroleum system of the basin has three main potential source rocks: (1) the Blue Lias Fm and Liassic Clays, (2) the Oxford Clay Fm and (3) the Kimmeridge Clay Fm (Fig. 3). Some other formations, such as the Nothe Clay (Oxfordian), the Gault Clay (Albian) and the Purbeck Black Shale (Berriasian), have good generative potential or good TOC values (Akande, 2012). In the Liassic and Kimmeridgian clays, the organic matter is of Type II, with a minor amount of Type III (Ebukanson and Kinghorn, 1986). Some potential source horizons are of Type I (Williams, 1986). Organic matter is quite abundant (Ebukanson and Kinghorn, 1985): up to $8 \%$ of Total Organic Carbon (TOC) for the Liassic Clays and about $20 \%$ for the Kimmeridge Clays. The maturity of source rocks in the Wessex Basin is still under discussion. Ebukanson and Kinghorn (1985) assumed that source rocks are immature, according to values of vitrinite reflectance, which are no more than $0.48 \%$ for the Kimmeridge Clay Fm. Nevertheless, some other authors demonstrated that the maturity of the Kimmeridge Clay Fm could be higher than previously thought. More recently, Akande (2012) showed, by coupling Rock-Eval and TOC analyses, that all potential source of petroleum substance rocks in the Wessex Basin could be more mature, especially the Blue Lias Fm and the Kimmeridge Clay Fm. According to his results, both of these reached the oil window. Furthermore, Bray et al. (1998) demonstrated, via Apatite Fission Track Analyses (AFTA), that the source rocks should have reached maturity some time ago and that hydrocarbon generation is a consequence of a very complex thermal history, due to several phases of uplift and erosion. Thus hydrocarbon generation was widespread through time, from the midJurassic ( 170 Ma) to the late Tertiary ( 20Ma). At each locality within the Basin, hydrocarbon generation peaked at a specific point in time. When plotted on a map, these peaks are seen to become progressively younger, as one goes eastward.

Other evidence for fluid migration is visible, in the form of bitumen and 'beef' veins. Thus Lee and Cox (1937, page 164) indicated that, "veinlets of hard bitumen, which must originally have been fluid, occur in the Belemnite Marls, the Black Ven Marls, and in parts of the Blue Lias of Dorset". 'Beef' has been described at many localities in the Wessex Basin. At first, such veins in the Liassic rocks of the Dorset coast may have seemed to be of no more than local interest. However, other examples later came to light at many stratigraphic levels and 
locations, such as (1) the Blue Lias and Liassic Clays of Early Jurassic age at Lyme Regis and Charmouth (Sorby, 1860; Woodward, 1893; Lang, 1914; Lang et al., 1923; Lang and Spath, 1926; Marshall, 1982; Simms, 2004; Gallois, 2008; Paul et al., 2008; Gallois and Paul, 2009) as well as in East Devon (Page, 2002), (2) the Kimmeridge Clay of Late Jurassic age at Kimmeridge Bay (Coe et al., 1999; Morgans-Bell et al., 2001), (3) the Purbeck Beds of Early Cretaceous age at Swanage (Webster, 1826; Buckland and De la Beche, 1835; El-Shahat and West, 1983), (4) the Purbeck Beds of the Vale of Wardour (Brodie, 1854; Andrews, 1881; Andrews and Jukes-Brown, 1894; Reid, 1903; Simms, 2004; Hopson et al., 2006; Palmer, 2014), (5) two distinct formations on the Isle of Wight, the Vectis Formation of Early Cretaceous age (Judd, 1871; Hopson et al., 2008) and the Wealden Group (Radley et al., 1998; Zanella et al., 2011), (6) the Purbeck Beds of Sussex (Howitt, 1964) and (7) the Purbeck Beds of the Weymouth Relief Road (Woods, 2009). Few of these studies addressed the origin of such 'beef'. An exception was the isotopic study of Marshall (1982), who identified large variations in $\delta^{18} \mathrm{O}$ along fibres and suggested that external fluid flowed in a bedding-parallel direction, supplanting the idea of precipitation from connate waters. Variations in $\delta^{13} \mathrm{O}$ values are also large (from nearly -17\%o to $0 \%$; Marshall, 1982, his figure 5). Marshall attributed these variations to the successive involvement of carbon, deriving mainly from organic matter, or from marine or connate waters. In contrast, Kiriakoulakis et al. (2000) suggested that the calcite fibres forming the concretions of the Birchi Bed (upper part of the 'Shales-with-Beef') are the result of early diagenetic (late bacterial) processes.

More recently, Worden et al. (2015) focussed their study on calcite veins in relation to fault systems in the Wessex Basin. They concluded that fluid migration occurred throughout the Wessex Basin and that calcite crystallized in veins at temperatures between $50^{\circ}$ and $70^{\circ} \mathrm{C}$, especially within Jurassic, Lower Cretaceous and Upper Cretaceous host-rocks. Nowhere did they mention bedding-parallel calcite 'beef' or any of the previous publications, which had referred to that.

\section{Field Data}

In the Wessex Basin, 'beef' is visible along many of the coastal cliffs (Fig. 5). Previous studies had described 'beef' within shale or mudstone at 6 stratigraphic levels in the basin. During our study, we investigated the entire stratigraphic sequence. As a result, we also found 'beef' in (8) the Blue Lias at Chippel Bay (Figs. 6 \& 7), (9) the Oxfordian Clays at Osmington Mills and at Ringstead Bay, (10) the Purbeck Beds at Durdle Door, Stair Hole, 
Lulworth Cove (see the website of West, 2013) (Figs. 8 \& 9), Mupe Bay and Worbarrow Bay, and (11) Early to Middle Cretaceous strata at Sandown and Brighstone Bay on the Isle of Wight. Thus 'beef' occurs in Mesozoic strata, from Liassic to Middle Cretaceous ages (Fig. 3). This time span matches those of the source rocks and reservoirs (Fig. 3). Calcite is the main constituent mineral of the 'beef', but we also found pyrite and shale particles within it and these probably contribute to the typical grey colour of the 'beef' (for more information about the composition of 'beef' veins, please refer to section 4). Throughout the Wessex Basin, we have found no obvious correlation between the dimensions of 'beef' veins, their total volumes and their stratigraphic positions. The veins are typically a few millimetres to 34 decimetres thick (reaching 20 centimetres at Lyme Regis and $30 \mathrm{~cm}$ at Charmouth) and from several centimetres to tens of meters in length, so that many of them have very planar aspects. At outcrop scale, 'beef' veins commonly appear at several levels within the same formation. At some localities, for example in the 'Shales-with-Beef' Member at Lyme Regis, veins are very small but numerous (Fig. 7). Structurally, although most 'beef' veins are parallel to bedding, some of them are of variable thickness, due to folding or faulting during growth of the veins (Fig. 9).

According to several authors (e.g. Lang et al. 1923; Webster 1926; Woods 2009; Zanella et al. 2011), 'beef' seems to have formed more readily in impermeable shale or mudstone. During our fieldwork, we found (using hydrochloric acid) that the more carbonaterich the host rock, the more abundant the 'beef'. As an extreme, carbonate-free levels of clayrich sediment are devoid of 'beef'. Thus the mineralogical composition of the host rock may have exerted a local chemical control on the fluid-rock system. For all that, 'beef' veins seem to be, not local structures, but widespread at the scale of the Wessex Basin (Fig. 5).

Two localities in the Wessex Basin are especially worthy of description: Lyme Regis and Lulworth Cove. Both are historical and easily accessible areas, having good examples of easily observable 'beef'. However, the nature of the 'beef' differs strongly, from one locality to the other. At Lyme Regis the lowermost formations exposed are Lower Jurassic in age and thus correspond to the base of the petroleum system in the Wessex Basin. Here 'beef' veins are of almost uniform thickness, indicating little or no deformation, other than vertical opening. In contrast, at Lulworth Cove the 'beef' varies in thickness across folds and faults. Such deformation is most obvious in the vicinity of the Purbeck - Isle of Wight fault system (Fig. 9). Also visible at Lulworth Cove are numerous steeply dipping calcite veins, which almost certainly imply a vertical component of fluid migration. 


\subsection{Lyme Regis outcrops}

About 600 metres west of Lyme Regis port, cliffs line the coast between Chippel Bay and Seven Rock Point. Outcropping strata, from the Blue Lias Formation (Top of Hettangian) to the 'Shales-with-Beef' Member (Sinemurian), are mainly of alternating shale and limestone (Figs. 2 \& 6). The beds are nearly flat-lying across a gentle anticline, trending N-S (Fig. 6). At outcrop we identified one vertical strike-slip fault, but this has little effect on the overall structure.

In this area, 'beef' is especially abundant within shale, especially in the 'Shales-withBeef' Member, visible at the top of the cliff (Lang et al. 1923; Fig. 7). Here, 'beef' veins are numerous and continuous and, being hard, they protrude. Indeed, these were the levels that Marshall (1982) studied (Fig. 7B). Since then, episodic landslides have provided some excellent fresh exposures. As well as continuous layers of 'beef', the formation also contains many small 'beef' veins within the entire thickness of the organic-rich shale formation.

In the Blue Lias Formation, we have identified 10 levels of 'beef' (Fig. 7A). In dark organic-rich marly shale, 'beef' veins are parallel to bedding. Calcite fibres are easily visible and have formed perpendicular to the margins and thus appear to be perpendicular to bedding. In some examples, 'beef' veins are shorter and overlap 'en échelon' (Fig. 7A). The thickness of the 'beef' veins varies from several millimetres to 1 - 2 centimetres (Fig. 7C). The length of each vein is more variable, from several centimetres to tens of metres. Some of the thinnest 'beef' veins are difficult to distinguish, especially those at low levels, between the " 2 nd $T a p e$ " and “ 3 rd Quick” strata (Fig. 7A).

Eastward from Lyme Regis to Charmouth, 'beef' occurs within strata of the Blue Lias and the Charmouth Mudstone. Nevertheless, between both towns, landslides are common and outcrops are very unpredictable and hazardous. In this area, Lees \& Cox (1937) also reported bitumen veinlets in the Black Ven Marls, the Belemnite Marls and the Blue Marls (Liassic Clays). However, they did not specify exact localities for these veinlets. In the same area, we identified some small fragments of bitumen veins within shale and some larger loose fragments in coastal landslides.

\subsection{Lulworth Cove outcrops}

Outcrops at Lulworth Cove are easily accessible at low tide. Here the Purbeck - Isle of Wight fault system, trending E-W, cuts through the entire sedimentary sequence, which dips 
locally towards the North, forming the limb of a monocline, due to basin inversion (Figs. 4A \& 8). From Durdle Door in the West, through Stair Hole and Lulworth Cove, to Mupe Bay and Worbarrow Bay in the East, outcropping Cretaceous strata range in age from the Portland Beds to the Chalk Group (Fig. 3). The best outcrop of 'beef' is on the eastern side of Lulworth Cove (red box, Fig. 8), immediately above the uppermost limestone bed of the Upper Purbeck Fm. We have also seen 'beef' at about 2 metres beneath the Cinder Bed at Stair Hole, but veins become more numerous in the Upper Purbeck Beds (for example those of Lulworth Cove, Fig. 9). Most commonly, the 'beef' veins are within mudstone.

As at Lyme Regis, so at Lulworth Cove, 'beef' veins are grossly parallel to bedding. However, at Lulworth Cove the veins are generally thicker (20 to $30 \mathrm{~cm}$ ) and the width changes, across internal folds (Fig. 9B) or faults (Fig. 9D). In many examples, calcite fibres are somewhat sigmoidal and longer within synclines (Fig. 9C). Indeed, fold trains of 'beef' are asymmetrical, having thicker synforms and thinner antiforms (Fig. 9B). This indicates that 'beef' vein development was synchronous with tectonic activity. Moreover, curved 'beef' fibres indicate shearing along the edges of some veins (Fig. 9C). The fibres grew progressively and the veins continued to open, while they were subject to shortening along the bedding. Thus fibre growth took place during horizontal shortening. Rodrigues et al. (2009, their figure 11, parts $A$ to $G$ ) described similar evidence for shortening, in the form of folding and faulting, during growth of calcite 'beef' in the Neuquén Basin of Argentina.

At some localities (especially at Stair Hole, West of Lulworth Cove), steep cross-cutting veins of white and sparry calcite are also visible. These veins cut through flat-lying shales and calcareous beds of the Purbeck Fm and do not reach the main 'beef' level (just above the Upper Purbeck limestone). The veins are several metres long, but only 1 or $2 \mathrm{~cm}$ thick, and they are perpendicular to the hinge of the regional anticline.

\section{Composition of 'beef' veins}

Structurally, 'beef' veins consist of fibres, which are perpendicular (or almost so) to the vein margins. Nevertheless, most of the 'beef' veins in the Wessex Basin contain multiple nested cones, which are tight and typical of cone-in-cone structures. Good examples are visible at Lulworth Cove (Fig. 9C).

To investigate the composition of 'beef' veins in the Wessex Basin, we carried out ESEM analyses at 5 localities (Fig. 10). All of this 'beef' consists basically of calcite. 
However, some pyrite is present between calcite fibres and fragments of shale are also visible (Fig. 10). Moreover, an important observation is the presence of hydrocarbons within the 'beef' veins. These are visible as concentrations of carbon on ESEM images (Fig. 10). The hydrocarbons are either liquid or solid and thus appear to be, respectively, oil or bitumen. They are disseminated through the 'beef', either between calcite fibres ("patches", Fig. 10) or within crystals (“inclusions", Fig. 10). These inclusions are distinguishable by their very smooth contours and dot-like forms on ESEM images. Such hydrocarbons appear to be present in all the samples of 'beef' that we have analyzed.

\section{Discussion}

\subsection{Distribution of 'beef' veins}

Calcite minerals with some pyrite and fragments of shale make up the 'beef' veins of the Wessex Basin. Bitumen is present within the 'beef' between fibres of calcite or as inclusions within crystals. At the basin scale, 'beef' veins are very widespread. They are distributed within shales and mudstones of the basin, essentially near or within potential source rocks for petroleum. Nevertheless, 'beef' also occurs in shales of the petroleum system overburden, close to regional tectonic structures, such as the Purbeck - Isle of Wight fault system. This is in particularly well seen at the localities of Lulworth Cove and Swanage. Thus the distribution of 'beef' seems to be, not random, but dependent on various parameters. Such parameters have been already investigated, in particular by Rodrigues (2008) for the Neuquén Basin in Argentina. In that study, the author determined a geochemical relationship between 'beef' veins and calcite of the host rock. He concluded that the carbonate composition of the source rock for petroleum, which is also the host rock for the 'beef', controls the distribution and the composition of 'beef' veins. By analogy, for the Wessex Basin, the carbonate composition of the host rock would seem to have the same effects on the 'beef' veins.

Worden et al. (2015) studied calcite veins in the Wessex Basin. They focussed their study on veins associated with faults and not at all on the 'beef'. We notice that, in terms of composition, fault-related veins are similar to 'beef'. Both sets contain calcite crystals and hydrocarbons. Thus they may have formed under similar conditions. This may explain why, when 'beef' is not within a potential source rock, it occurs near major faults of the Wessex Basin. 


\subsection{Origin and timing of generation of 'beef' veins}

'Beef' veins of the Wessex Basin affect much of the Mesozoic sedimentary infill. Nevertheless, as previously described, these veins are especially common within potential source rocks for petroleum, in other words, shales and mudstones. The origin of 'beef' would seem to be due to fluid overpressure, especially within shales (Rodrigues et al. 2009; Zanella et al. 2011; Cobbold et al. 2013). Zanella et al. (2014a) used physical models to verify that chemical compaction, during the maturation of organic matter, leads to overpressure and natural hydraulic fracturing. In the Wessex Basin, 'beef' contains significant amounts of hydrocarbons, as inclusions within calcite crystals. This argues in favour of synchronicity between 'beef' crystallization and hydrocarbon migration. Thus the origin of 'beef' veins in the Wessex Basin is linked with the generation and migration of hydrocarbons. These veins provide evidence at outcrop for natural hydraulic fracturing. All this is in agreement with data from Akande (2012), who demonstrated that the source rocks in the Wessex Basin are more mature than most people previously thought.

There is considerable evidence in the Wessex Basin that the generation of hydrocarbons started in the Early Cretaceous to Palaeogene and reached a peak during early Tertiary times (Bray et al. 1998). Synchronously with this generation, tectonic inversion of the Wessex Basin took place from the Late Cretaceous to the Tertiary (Underhill and Stoneley, 1998). At localities like Lulworth Cove, this proposed link between the tectonic deformation and beef formation probably explains the differential thicknesses of 'beef' veins, their curved calcite fibres, and their inclusions of hydrocarbons.

\section{Conclusions}

In the Wessex Basin, bedding-parallel veins of fibrous calcite ('beef') are widespread within Mesozoic shale and mudstone. The 'beef' is regionally quite homogeneous in composition. It consists of calcite fibres and intervening grains of pyrite or shale. Liquid or solid hydrocarbons are also present between fibres or as inclusions within crystals of calcite. This demonstrates that liquid hydrocarbons were present during crystallization of 'beef' veins. The formation of 'beef' was synchronous with the migration of hydrocarbons in the basin. That is why 'beef' contains such hydrocarbons. We therefore should envisage the synchronous migration of two fluid phases: an aqueous phase and hydrocarbons. The thickness of 'beef' veins tends to be uniform, in areas where tectonic deformation is gentle, but 
highly variable near major tectonic faults. At Lulworth Cove, veins show internal folds and faults, which developed while the calcite fibres were growing. This suggests that some 'beef' veins were forming during compressional deformation and Upper Cretaceous to Tertiary inversion of the Wessex Basin. From this our study of the Wessex Basin, as well as another study of the Neuquén Basin, we believe that 'beef' is a strong marker of fluid overpressure and hydrocarbon generation and suggest that further studies of 'beef' could provide important insights into the mechanical and chemical processes operating during the evolution of a petroleum system.

\section{Acknowledgements}

We would like to thank (1) Dr. Ian West of Southampton University for the help that he has given us since the year 2005 in connection with the Wessex Basin and (2) Statoil, for funding this project of Alain Zanella.

\section{References}

Akande W.G., 2012. Assessment of thermal maturity of the Mesozoic organic-rich rocks of southern England. The Pacific Journal of Science and Technology 13 (2), 407-416.

Andrews, W.R., 1881. Note on the Purbeck Beds at Teffont. Quarterly Journal of the Geological Society, London 37, 251-253.

Andrews, W.R., Jukes-Brown, A.J., 1894. The Purbeck Beds of the Vale of Wardour. Quarterly Journal of the Geological Society, London 50, 44-71.

Bons, P.D., Jessell, M.W., 1997. Experimental simulation of the formation of fibrous veins by localised dissolution-precipitation creep. Mineralogical Magazine 61, 53-63.

Bray, R.J., Duddy, I.R., Green, P.F., 1998. Multiple heating episodes in the Wessex Basin: implications for geological evolution and hydrocarbon generation. Geological Society, London, Special Publications 133, 199-213.

Brodie, P.B., 1854. On the insect beds of the Purbeck Formation in Wiltshire and Dorsetshire. Quarterly Journal of the Geological Society, London 10, 475-482. 
Buchanan, J.G., 1998. The exploration history and controls on hydrocarbon prospectivity in the Wessex basins, southern England, UK. Geological Society, London, Special Publications 133, 19-37.

Buckland, W., De la Beche, H.T., 1835. On the geology of the neighbourhood of Weymouth and the adjacent parts of the coast of Dorset. Transactions of the Geological Society, London s2-4, 1-46.

Campos, H.S., Hallam, A., 1979. Diagenesis of English Lower Jurassic limestones as inferred from oxygen and carbon isotope analyses. Earth and Planetary Science Letters, 45, 23-31.

Chadwick, R.A., Kenoulty, N., Whittaker, A., 1983. Crustal structure beneath southern England from deep seismic reflection profiles. Journal of the Geological Society, London 140, 893-912.

Cobbold, P.R., Rodrigues, N., 2007. Seepage forces, important factors in the formation of horizontal hydraulic fractures and bedding-parallel fibrous veins ('beef' and 'cone-incone'). Geofluids 7, 313-332.

Cobbold, P.R., Zanella, A., Rodrigues, N., Løseth, H., 2013. Bedding-parallel fibrous veins (beef and cone-in-cone): worldwide occurrence and possible significance in terms of fluid overpressure, hydrocarbon generation and mineralization. Marine and Petroleum Geology 43, 1-20. doi: 10.1016/j.marpetgeo.2013.01.010.

Cobbold, P.R., Zanella, A., Fourdan, B., Néraudeau, D., Gouttefangeas, F., 2015. Natural hydraulic fractures in the Eastern Paris Basin. Bulletin d'Information des Géologues du Bassin de Paris 52, 24-31.

Coe, A.L., Hesselbo, S.P., Jenkyns, H.C., Morgans Bell, H., Weedon, G.P., 1999. Kimmeridge Clay Formation composite graphic log for coastal exposures, near Kimmeridge, Dorset. Supplementary Publication No. SUP 90490, British Library. Associated with paper by Morgans-Bell, Coe, Hesselbo, Jenkyns, Weedon, Marshall, Tyson and Williams (2001).

Cosgrove, J.W., 1995. The expression of hydraulic fracturing in rocks and sediments. In: Ameen, M.S. (Ed.), Fractography: Fracture Tomography as a Tool in Fracture Mechanics and Stress Analysis. Geological Society, London, Special Publications 92, 187-196. 
Cosgrove, J.W., 2001. Hydraulic fracturing during the formation and deformation of a basin: a factor in the dewatering of low-permeability sediments. American Association of Petroleum Geologists Bulletin 85, 737-748.

Denaeyer, M.-E., 1943. Les cone-in-cone de la France métropolitaine et d'outre-mer. Bulletin de la Société française de Minéralogie 66 (1-6), 173-221.

Denaeyer, M.-E., 1947. Les gisements de cone-in-cone de France et de Grande-Bretagne. Deuxième Partie. Gisements britanniques. Bulletin de la Société belge de Géologie, de Paléontologie et d'Hydrologie 56 (3), 382-411.

Dobes, P., Suchy, V., Stejskal, M., 1999. Diagenetic fluid circulation through fractures: a case study from the Barrandian Basin (Lower Paleozoic), Czech Republic. Geolines (Praha) 8, 18.

Durney, D.W., Ramsay, J.G., 1973. Incremental strains measured by syntectonic crystal growths. In: De Jong, K.A., Scholten, R. (Eds.), Gravity and Tectonics. Wiley, New York, pp. 67-96.

Ebukanson, E.J., Kinghorn, R.R.F., 1985. Kerogen facies in the major mudrock formations of Southern England and the implication on the depositional environments of their precursors. Journal of the Petroleum Geology 8, 435-462.

Ebukanson, E.J., Kinghorn, R.R.F., 1986. Maturity of organic matter in Jurassic of Southern England and its relation to the burial history of the sediments. Journal of Petroleum Geology 9, 259-280.

El-Shahat, A., West, I., 1983. Early and late lithification of aragonitic bivavlve beds in the Purbeck Formation (Upper Jurassic - Lower Cretaceous) of southern England. Sedimentary Geology, 35, 15-41.

Gale, J.F.W., Laubach, S.E., Olson, J.E., Eichhubl, P., Fall, A., 2014. Natural fractures in shale: A review and new observations. American Association of Petroleum Geologists Bulletin 98 (11), 2165-2216. 
Gallois, R.W., 2008. The lithostratigraphy of the Shales-with-Beef Member of the Charmouth Mudstone Formation, Lower Jurassic. Geoscience in South-West England, Proceedings of the Ussher Society 12, 32-40.

Gallois, R.W., Paul, C.R.C., 2009. Lateral variations in the topmost part of the Blue Lias and basal Charmouth Mudstone formations (Lower Jurassic) on the Devon and Dorset coast. Goescience in South-West England, Proceedings of the Ussher Society 12, 125-133.

Glennie, K.W., Underhill, J.R., 1998. Origin, development and evolution of structural styles. In: Glennie, K.W. (ed.), Petroleum Geology of the North Sea. Blackwell Scientific Publications, Oxford, 42-84.

Gratier, J.-P., Frery, E., Deschamps, P., Røyne, A., Renard, F., Dysthe, D., EllouzZimmerman, N., Hamelin, B., 2012. How travertine veins grow from top to bottom and lift the rocks above them: the effect of crystallization force. Geology 40 (11), 1015-1018, http://dx.doi.org/10.1130/G33286.1.

Gustavson, T.C., Hovorka, S.D., Dutton, A.R., 1994. Origin of satin spar veins in evaporite basins. Journal of Sedimentary Research A64, 88-94.

Hawkes, P. W., Fraser, A. J., Einchcomb, C.C.G., 1998. The tectono-stratigraphic development and exploration history of the Weald and Wessex basins, Southern England, UK. Geological Society, London, Special Publications 133 (1), 39-65.

Hopson, P.M., Farrant, A.R., Newell, A.J., Marks, R.J., Booth, K.A., Bateson, L.B., Woods, M.A., Wilkinson, I.P., Brayson, J., Evans, D.Y. 2006. Geology of the Salisbury Sheet Area. British Geological Survey, Internal Report IR/06/011, 244 pp.

Hopson, P.M., Wilkinson, I.P., Woods, M.A., 2008. A stratigraphical framework for the Lower Cretaceous of England. British Geological Survey Research Report RR/08/03, 177.

Howitt, F., 1964. Stratigraphy and structure of the Purbeck inliers of Sussex (England). Quarterly Journal of the Geological Society 120, 77-113.

Judd, J.W., 1871. On the Punfield Formation. Quarterly Journal of the Geological Society, London 27, 207-227. 
Keulen, N.T., den Brok, S.W.J., Spiers, C.J., 2001. Force of crystallisation of gypsum during hydration of synthetic anhydrite rock. 13th DRT conference, Deformation Mechanisms, Rheology, and Tectonics, Noordwijkerhout, The Netherlands.

Kiriakoulakis, K., Marshall, J.D., Wolff, G.A., 2000. Biomarkers in a Lower Jurassic concretion from Dorset (UK). Journal of the Geological Society 157 (1), 207-220.

Lake, S.D., Karner, G.D., 1987. The structure and evolution of the Wessex Basin, southern England: an example of inversion tectonics. Tectonophysics 137, 347-356, 358-378.

Lang, W.D., 1914. The geology of the Charmouth Cliffs, Beach and Foreshore. Proceedings of the Geological Association 25, 293-360.

Lang, W.D., Spath, L.F., 1926. The Black Marl of Black Ven and Stonebarrow, in the Lias of the Dorset Coast. Quarterly Journal of the Geological Society, London, 82, 144-165.

Lang, W.D., Spath, L.F., Richardson, W.A., 1923. Shales-With-'Beef', a sequence in the Lower Lias of the Dorset Coast. Quarterly Journal of the Geological Society, London 79, 47-99.

Lash, G.G., Engelder, T., 2005. An analysis of horizontal microcracking during catagenesis: example from the Catskill delta complex. American Association of Petroleum Geologists Bulletin 89, 1433-1449.

Lees, G.M., Cox, P.T., 1937. The geological basis of the present search for oil in Great Britain by the D'Arcy Exploration Company, Limited, Quarterly Journal of The Geological Society, London 93, 156-194.

Marshall, J.D., 1982. Isotopic composition of displacive fibrous calcite veins; reversals in pore-water composition trends during burial diagenesis. Journal of Sedimentary Petrology 52, 615-630.

Means, W.D., Li, T., 2001. A laboratory simulation of fibrous veins: some first observations. Journal of Structural Geology 23, 857-863.

Morgans-Bell, H.S., Coe, A.L., Hesselbo, S.P., Jenkyns, H.C., Weedon, G.P., Marshall, J.E.A., Tyson, R.V.,Williams, C.J., 2001. Integrated stratigraphy of the Kimmeridge Clay 
Formation (Upper Jurassic) based on exposures and boreholes in south Dorset, U.K. Geological Magazine 138, 511-539.

Page, K.N., 2002. A review of the ammonite faunas and standard zonation of the Hettangian and Lower Sinemurian succession (Lower Jurassic) of the east Devon coast (south west England). Geoscience in south-west England, 10, 293-303.

Palmer, J., 2014. Database of Roman Purbeck limestone: quarries. Internet page: http://www.palmyra.me.uk/archaeology.html

Parnell, J., Honghan, C., Middleton, D., Haggan, T., Carey, P., 2000. Significance of fibrous mineral veins in hydrocarbon migration: fluid inclusion studies. Journal of Geochemical Exploration 69-70, 623-627.

Paul, C.R.C., Allison, P.A., Brett, C.E., 2008. The occurrence and preservation of ammonites in the Blue Lias Formation (lower Jurassic) of Devon and Dorset, England and their palaeoecological, sedimentological and diagenetic significance. Palaeogeography, Palaeoclimatology, Palaeoecology 270, 258-272.

Radley, J.D., Gale, A.S., Barker, M.J., 1998. Derived Jurassic fossils from the Vectis Formation (Lower Cretaceous) of the Isle of Wight, southern England. Proceedings of the Geologists' Association, 109, 81-91.

Ramsay, J.G., 1980. The crack-seal mechanism of rock deformation. Nature 284, 135-139.

Reid, C., 1903. The geology of the country around Salisbury (Explanation of Sheet 298). Memoirs of the Geological Survey, England and Wales 298, 1-77.

Richardson, W.A., 1923. Petrology of the "Shales-with-Beef". Quarterly Journal of the Geological Society, London, 79, 88-89.

Rodrigues, N., 2008. Fracturation hydraulique et forces de courant: Modélisation analogique et données de terrain. Mémoire de doctorat, Université de Rennes 1, 164 pp.

Rodrigues, N., Cobbold, P.R., Løseth, H., Ruffet, G., 2009. Widespread bedding-parallel veins of fibrous calcite ('beef') in a mature source rock (Vaca Muerta Fm, Neuquén Basin, Argentina): evidence for overpressure and horizontal compression. Journal of the Geological Society, London 166, 695-709, http:// dx.doi.org/10.1144/0016-76492008- 
111.

Scotchman, I.C., 1989. Diagenesis of the Kimmeridge Clay Formation, onshore UK. Journal of the Geological Society, London, 146, 285-303.

Selley, R.C., 1992. Petroleum seepages and impregnations in Great Britain. Marine and Petroleum Geology, 9, 226-244.

Shearman, D.J., Mossop, G., Dunsmore, H., Martin, M., 1972. Origin of gypsum veins by hydraulic fracture. Institute of Mining and Metallurgy, Transactions B181, 149-155.

Simms, M.J., 2004. The Wessex Basin (Dorset and Central Somerset). In: British Lower Jurassic stratigraphy (edited by Simms, M.J., Chidlaw, N., Morton, M. \& Page, K.N.), Geological Conservation Review Series, No. 30, Joint Nature Conservation Committee, Chapter 2, 53-110.

Sorby, H.C., 1860. On the origin of "cone-in-cone". British Association for the Advancement of Science, Report of the 29th Meeting, 1859, Transactions of Sections, Geology, p. 124.

Spath, L.F., 1923. The ammonites of the Shales-with-Beef. Quarterly Journal of the Geological Society, London, 79, 66-88.

Stoneley, R., 1982. The structural development of the Wessex Basin. Journal of the Geological Society, London 139, 543-554.

Stoneley, R., 1983. Fibrous calcite veins, overpressures, and primary oil migration. American Association of Petroleum Geologists Bulletin 67, 1427-1428.

Stoneley, R., 1992. Review of the habitat of petroleum in the Wessex Basin: implications for exploration. Proceedings of the Ussher Society 8, 1-6.

Swarbrick, R.E., Osborne, M.J., Yardley, G.S., 2002. Comparison of overpressure magnitude resulting from the main generating mechanisms. In: Huffman, A.R., Bowers, G.L. (Eds.), Pressure Regimes in Sedimentary Basins and Their Prediction. American Association of Petroleum Geologists Memoir 76, 1-12.

Taber, S., 1918. The origin of veinlets in the Silurian and Devonian strata of New York. Journal of Geology 26, 56-63. 
Tarr, W.A., 1933. Origin of the "beef" in the Lias Shales of the Dorset Coast. Geological Magazine 70, 289-294.

Underhill, J.R., Paterson, S., 1998. Genesis of tectonic inversion structures: seismic evidence for the development of key structures along the Purbeck - Isle of Wight Disturbance. Journal of the Geological Society, London 155 (6), 975-992.

Underhill, J.R., Stoneley, R., 1998. Introduction to the development, evolution and petroleum geology of the Wessex Basin. Geological Society, London, Special Publications 133 (1), $1-18$.

Webster, T., 1826. Observations on the Purbeck and Portland Beds. In: Transactions of the Geological Society, London s2-2, 37-44.

West, I.M., 2013. Geology of the Wessex Coast of Southern England - the World Heritage Jurassic Coast - and More. Internet page: http://www.southampton.ac.uk/ imw/index.htm.

Woods, M.A., 2009. Weymouth Relief Road: temporary excavations in Jurassic and Cretaceous strata (May 2009). British Geological Survey Open Report OR/09/035, 1-6.

Woodward, H.B., 1893. The Jurassic rocks of Britain. Volume 3. The Lias of England and Wales (Yorkshire excepted). Memoir of the Geological Survey of the United Kingdom, 399 pp.

Worden, R.H., Benshatwan, M.S., Potts, G.J., Elgarmadi, S.M., 2015. Basin-scale fluid movement patterns revealed by veins: Wessex Basin, UK. Geofluids, 1-26.

Zanella, A., Cobbold, P.R., 2011. Influence of Fluid Overpressure, Maturation of Organic Matter, and Tectonic Context during the Development of 'beef ': Physical Modelling and Comparison With the Wessex Basin, SW England, vol. 13. EGU General Assembly, Vienna, Austria. Geophysical Research Abstracts.

Zanella, A., Cobbold, P.R., Le Carlier de Veslud, C., 2014a. Physical modelling of chemical compaction, overpressure development, hydraulic fracturing and thrust detachments in organic-rich source rock. Marine and Petroleum Geology 55, 262-274, doi: 10.1016/j.marpetgeo.2013.12.017. 
Zanella, A., Cobbold, P.R., Rojas, L., 2014b. Beef veins and thrust detachments in Early Cretaceous source rocks, foothills of Magallanes-Austral Basin, southern Chile and Argentina: structural evidence for fluid overpressure during hydrocarbon maturation. Marine and Petroleum Geology 55, 250-261, doi:10.1016/j.marpetgeo.2013.10.006.

Zanella, A., Cobbold, P.R., Ruffet, G., Leanza, H.A. 2015. Geological evidence for fluid overpressure, hydraulic fracturing and strong heating during maturation and migration of hydrocarbons in Mesozoic rocks of the northern Neuquén Basin, Mendoza Province, Argentina. Journal of South American Earth Sciences 62, 229-242.

\section{Figure captions}

Figure 1. A. Photograph of 'beef' vein (polished section) from Blue Lias Formation, between Lyme Regis and Charmouth, Dorset. 'Beef' consists mainly of crystalline calcite and its fibrous structure is typical. Grey colour is mainly due to presence of pyrite and shale fragments between fibres of calcite. Notice horizontal symmetry plane at centre of vein, from which 'beef' began to grow outwards. Second generation is visible at both edges of vein (below and above). B. Photograph of 'cone-in-cone' structure (bottom right) is from Chief Beef Member at Swanage, Dorset.

Figure 2. Geological map of Wessex Basin, SW England, including onland exposures and offshore structures (modified after Underhill \& Stoneley 1998). A corresponds to the NorthSouth cross section in Figure 4A.

Figure 3. Generalized stratigraphical column of Wessex Basin, (modified after Underhill \& Stoneley 1998; West 2013). Potential petroleum source rocks and conventional reservoirs are mainly within Mesozoic strata (especially Jurassic and Early Cretaceous). 'Beef' is also present (see right-hand column), especially in or near potential source rocks.

Figure 4. Geological cross-sections of the Wessex Basin. A: North-South cross-section of the basin showing the Purbeck fault, the major structure of the basin (modified after Underhill \& 
Stoneley 1998). B: Schematic East-West cross-section of the basin showing the general eastward dipping of the sedimentary fill and the differences in thickness for Cretaceous sediments.

Figure 5. Location map for 'beef' veins, which are visible at outcrops. The map is a combination of literature data and our experience in the field. The numbers refer to the following localities: (1) Chippel Bay and Monmouth Beach; (2) Church Cliffs and Charmouth; (3) Stonebarrow Hill; (4) Weymouth Relief Road; (5) Osmington Mills and Ringstead Bay; (6) Durdle Door; (7) St Oswald's Bay; (8) Stair Hole; (9) Lulworth Cove; (10) Mupe Bay; (11) Worbarrow Bay; (12) Kimmeridge Bay; (13) Chapman's Pool; (14) Durlston Bay and Peveril Point; (15) Brighstone Bay; (16) Sandown; (17) Vale of Wardour; (18) from Culverhole Point to Seven Rock Point (East Devon).

Figure 6. Panorama of Chippel Bay outcrops, westward from Lyme-Regis. Strata form very gentle anticline. The 'Shales-with-Beef' Formation (near top of cliff) is above the well-bedded Blue Lias Formation, which consists of alternating limestones and mudstones. For details, see Fig. 7.

Figure 7. Lyme-Regis outcrop observations. A. Schematic representation of local stratigraphic nomenclature for Blue Lias Fm. Notice multiple 'beef' layers (black, central column). B. Photograph of main 'beef' level in 'Shales-with-Beef' Fm. C. Photograph of typical 'beef' from Blue Lias Fm.

Figure 8. Panorama on eastern side of Lulworth Cove (red box refers to Figure 9). Main 'beef' veins are just above Upper Purbeck Beds, on the northern limb of an anticline, in the footwall of the Purbeck - Isle of Wight fault system (to the S, not visible here).

Figure 9. Outcrops of 'beef' veins, Lulworth Cove (for location, see Fig. 8). A. Main outcrop of beef veins. B. Folded beef. Thickness of 'beef' is variable (thicker in syncline, thinner in anticline). C. Curved calcite fibres, which compose layer of 'beef' within a syncline. Cone-incone structures are visible as well. D. Folded and faulted beef veins. Faults cut through 'beef' but not shale. Thicknesses of 'beef' veins vary across some faults and folds. 
Figure 10. Analyses by scanning electron microscopy (SEM) of 'beef' samples from 5 different localities (A to E) of the Wessex Basin. Composite BSE and X-ray images (right) show typical composition of 'beef'. Intensities of colours reveal concentrations of elements $($ red $=$ carbon; green $=$ aluminium; yellow $=$ sulphur; blue $=$ calcium $)$. 


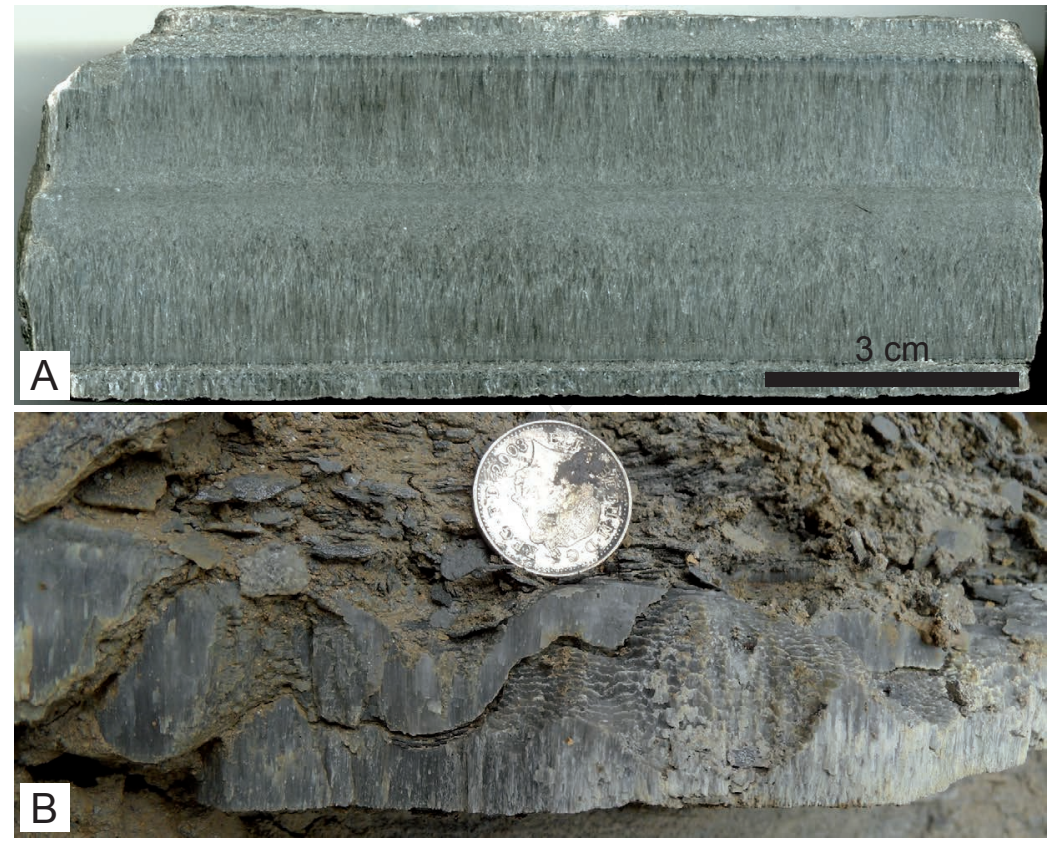




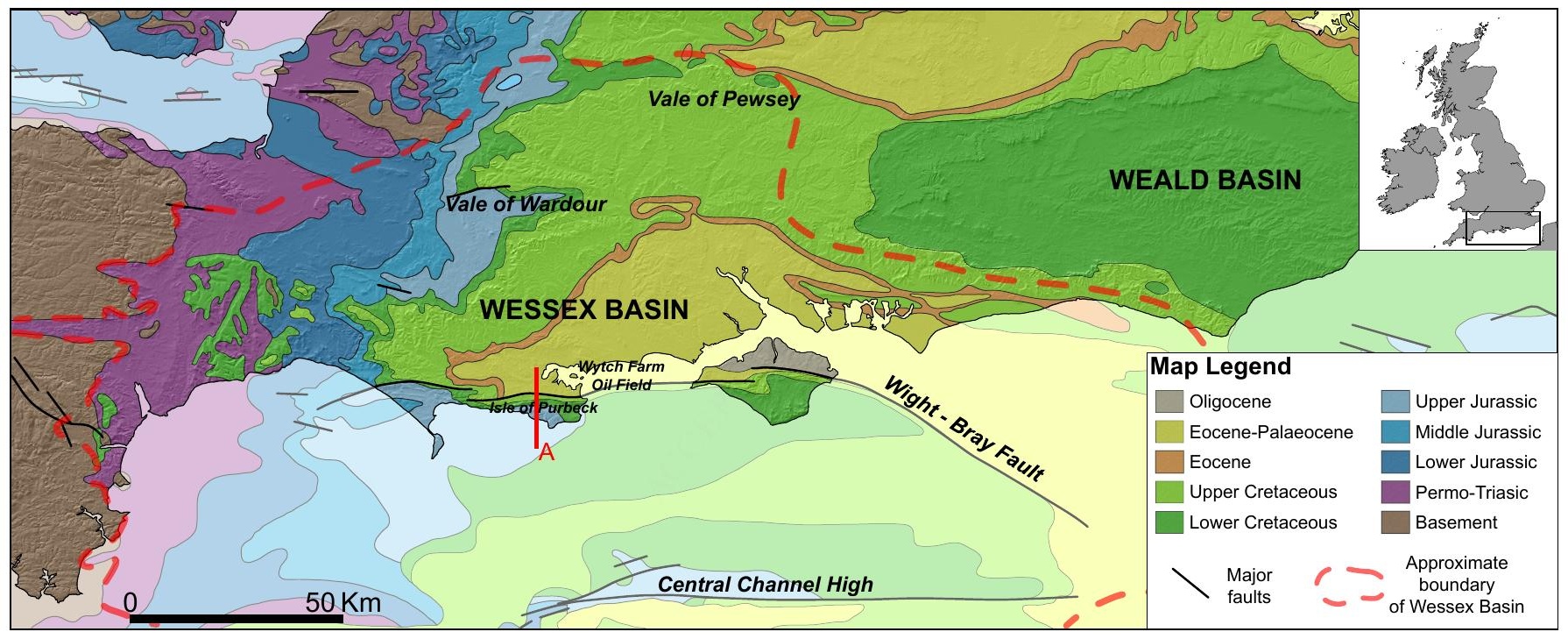




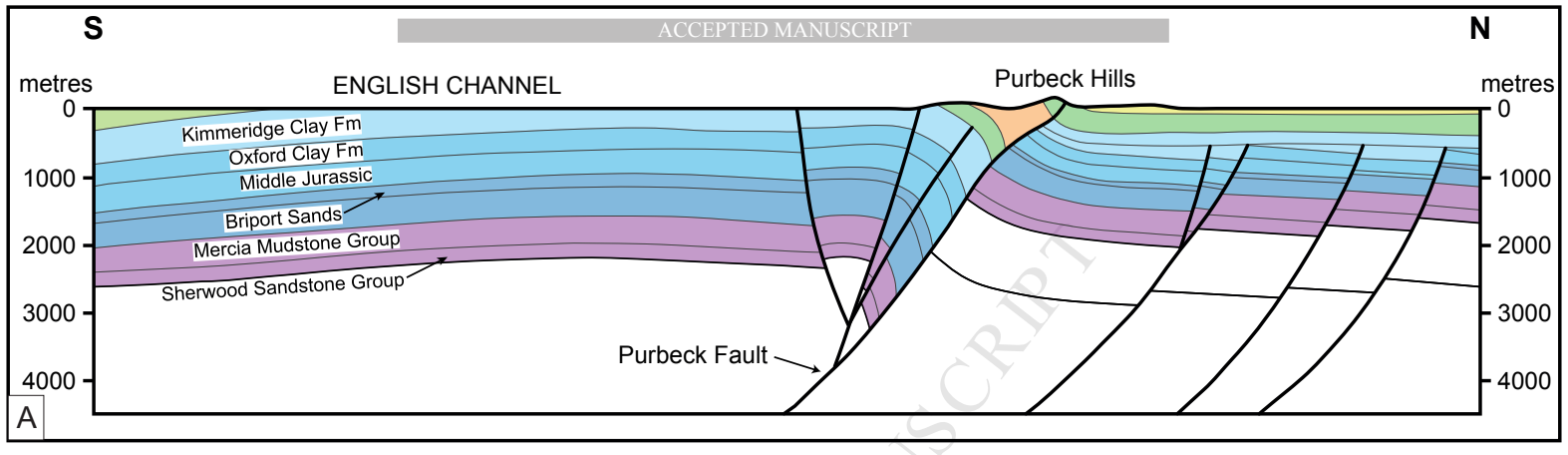

W

Haldon

Hill

Sidmouth Charmouth

Abbotsbury

Burning
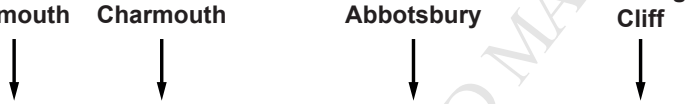

Swanage

Isle of

$\downarrow$

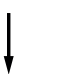

1

Wight
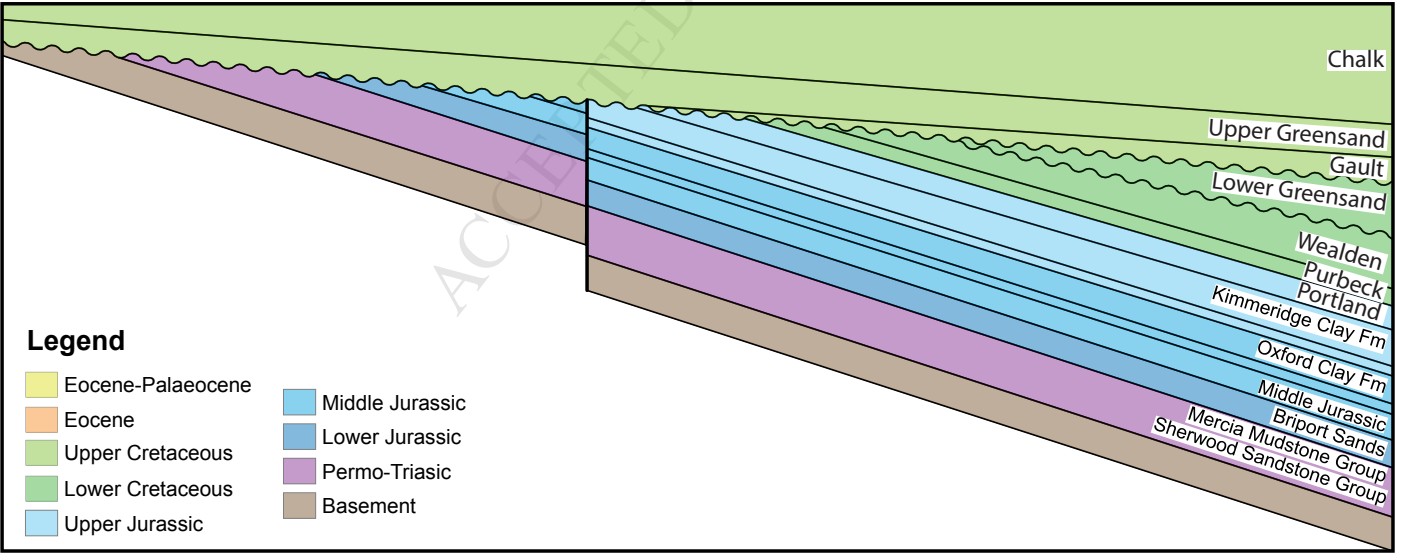


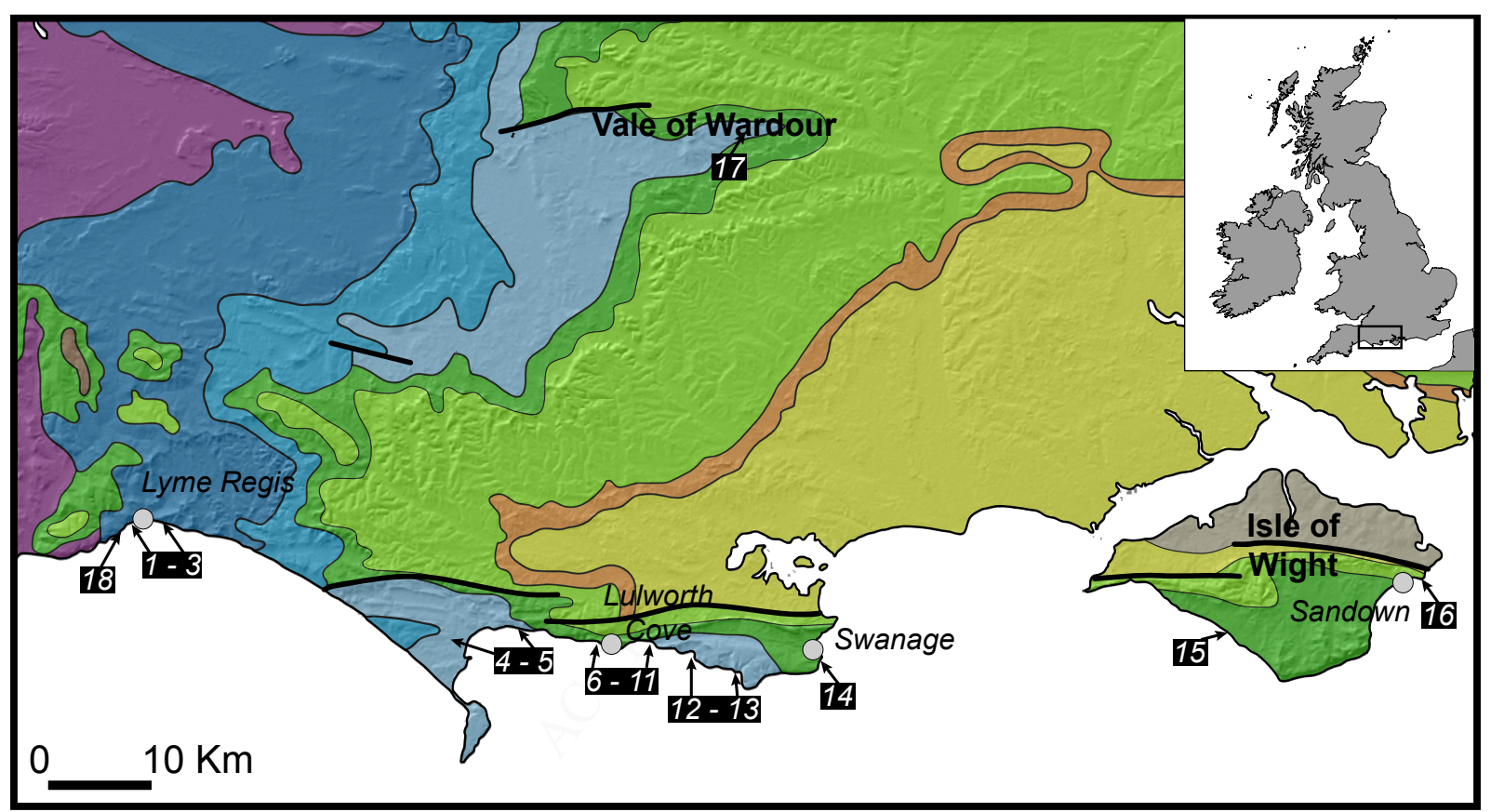

Oligocene Eocene-Palaeocene Eocene Upper Cretaceous Lower Cretaceous Upper Jurassic Middle Jurassic 


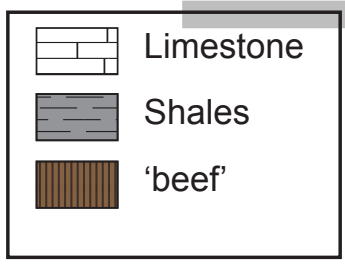

ACCEPTED MANUSCRIPT
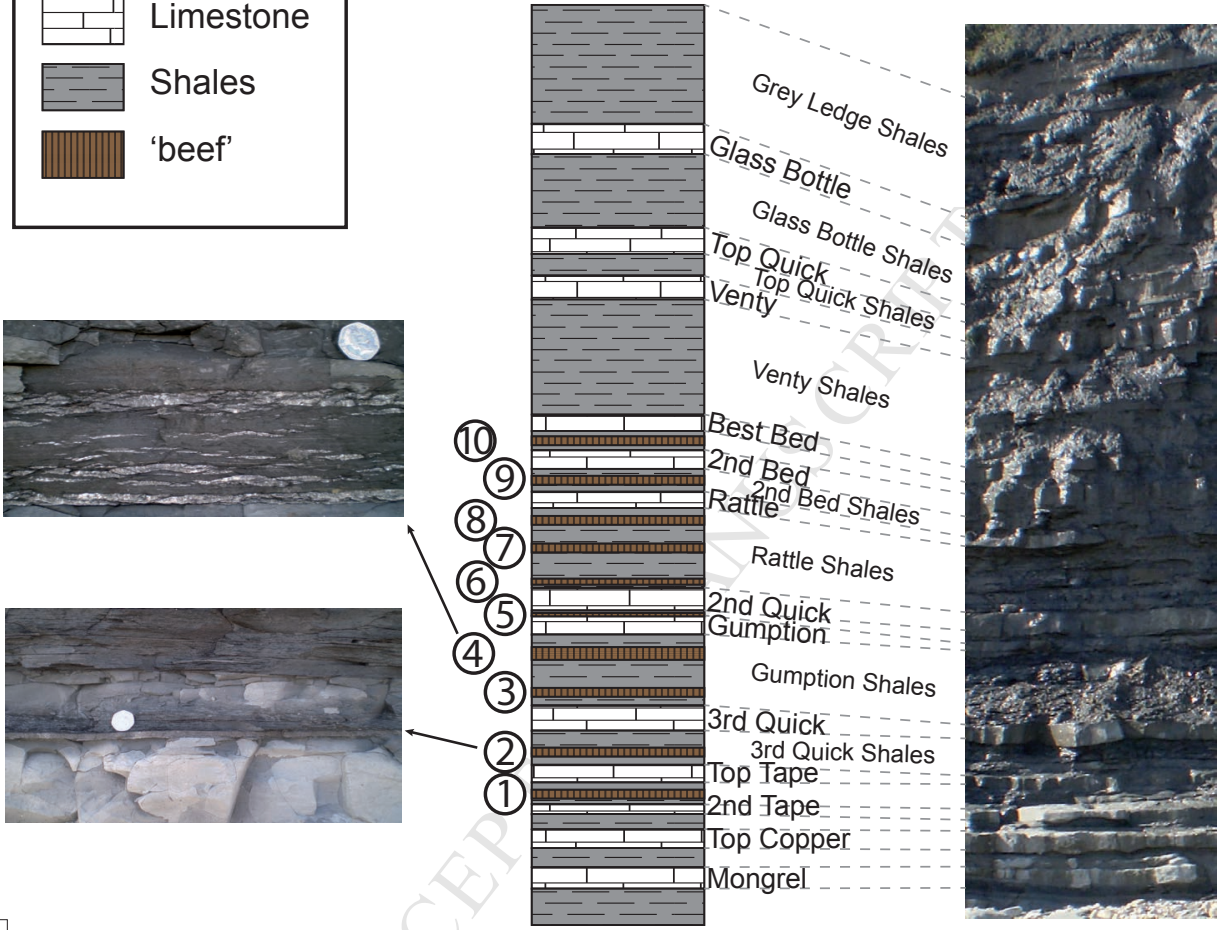

A
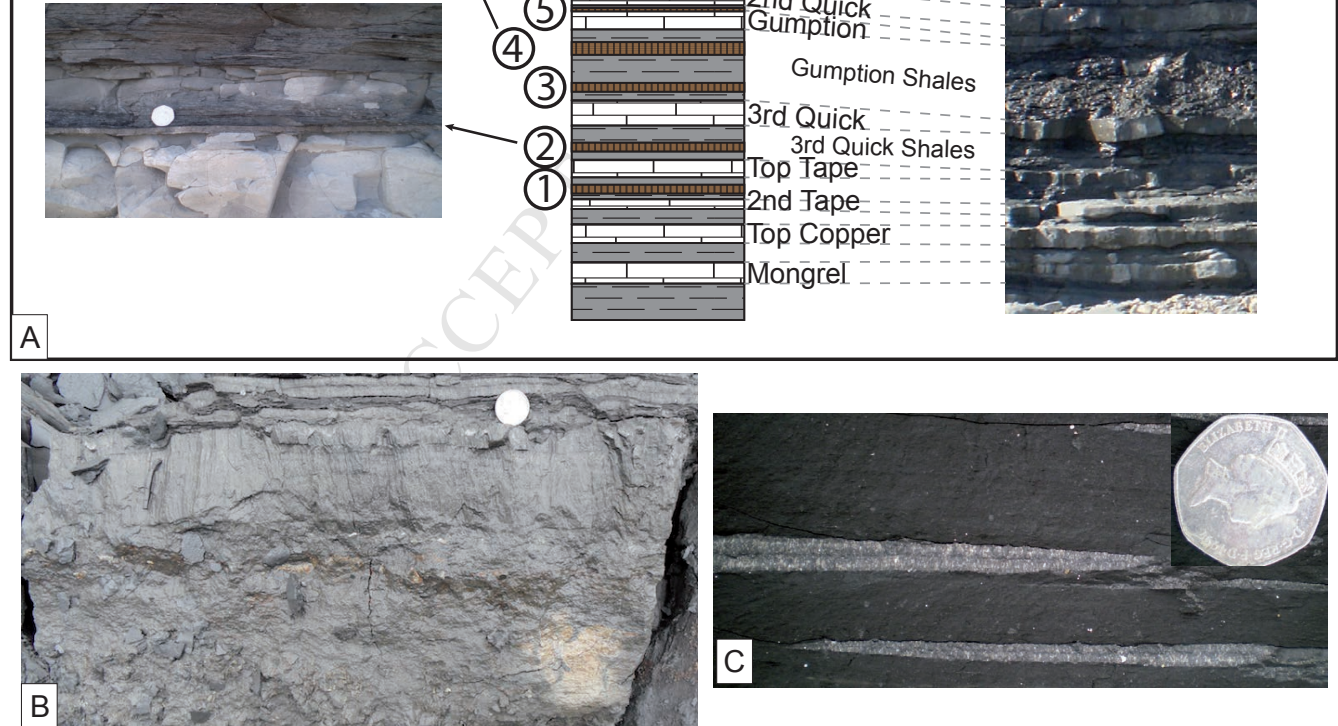


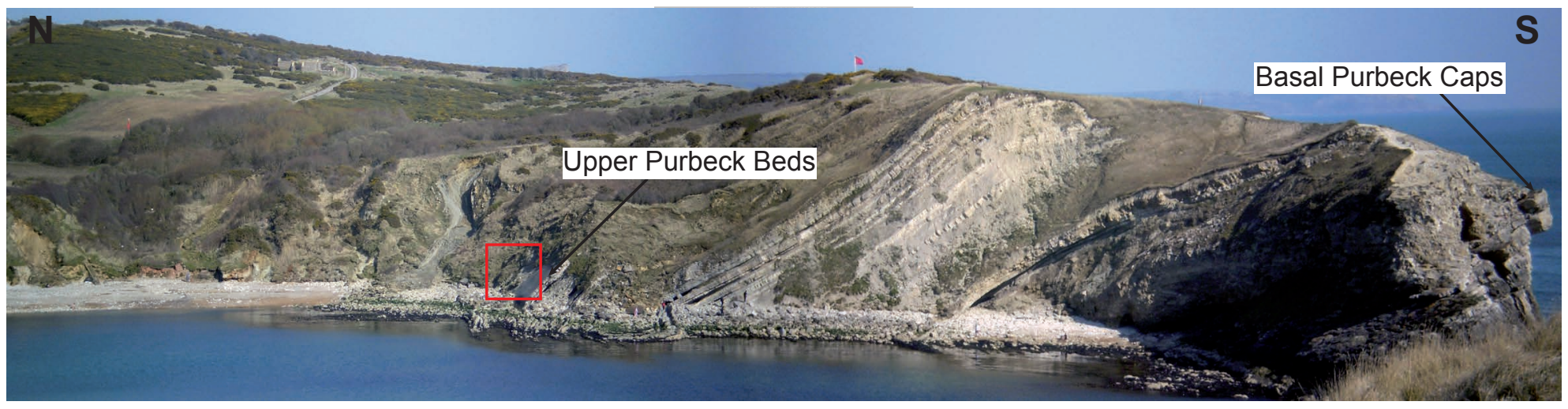




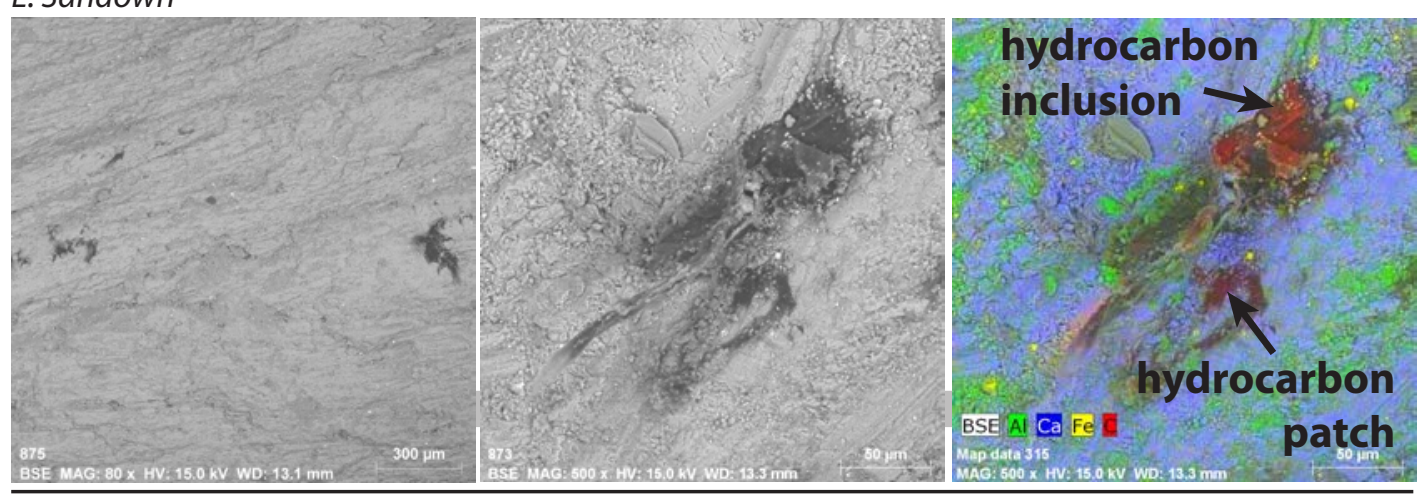

\section{Lulworth}
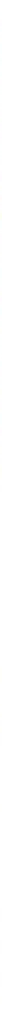

\section{B. Osmington}

8
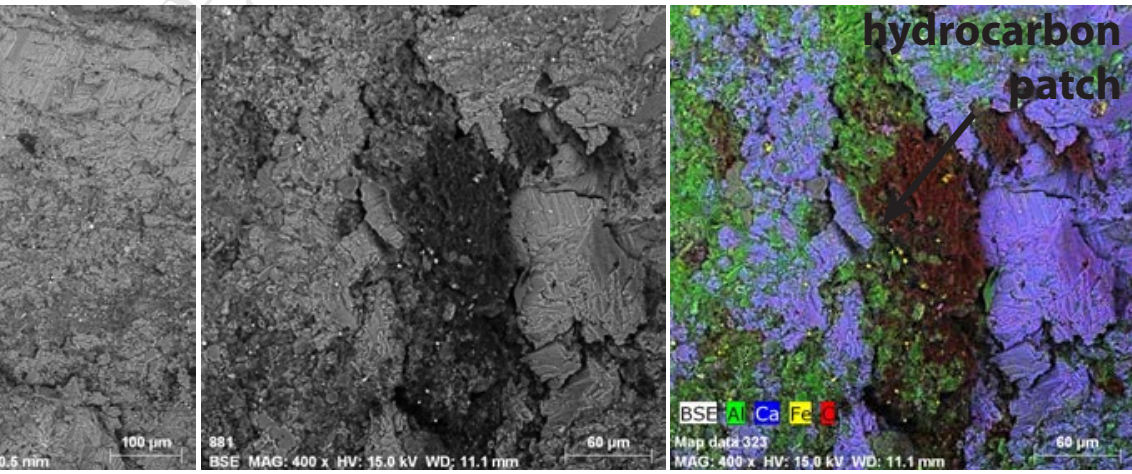

\section{A. Lyme Regis}

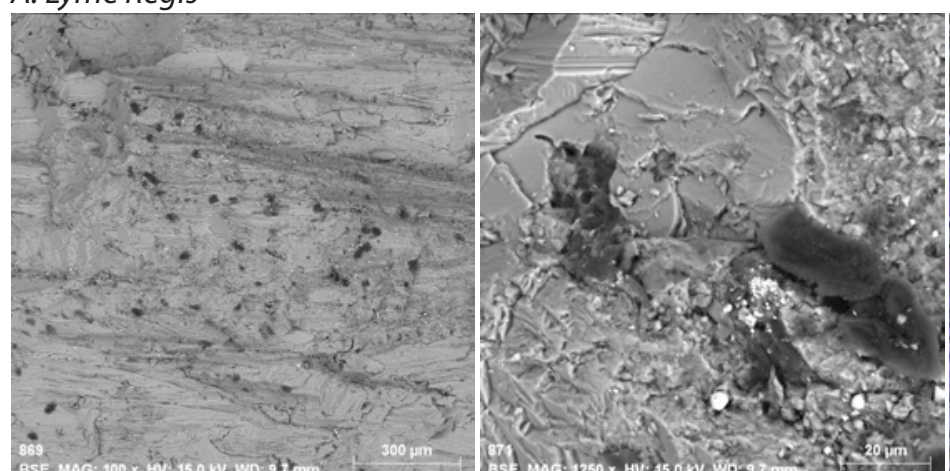

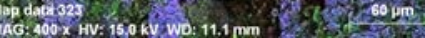

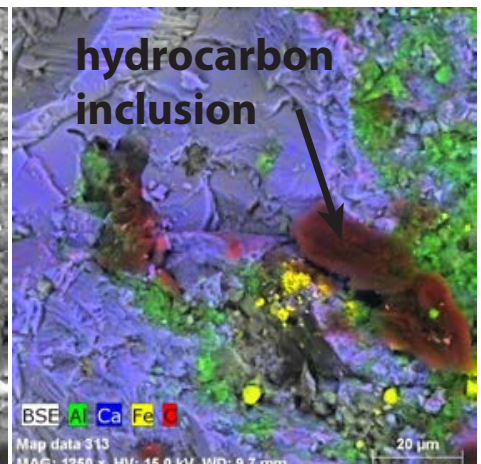




\section{Natural hydraulic fractures in the Wessex Basin, SW England: widespread distribution, composition and history}

\section{Highlights}

1. 'Beef' veins (natural hydraulic fractures) are widespread in the Wessex Basin.

2. 'Beef' veins are distributed within Mesozoic shales or mudstones.

3. Hydrocarbons are present within the fibres of 'beef' veins.

4. The development of 'beef' has been synchronous with hydrocarbon generation.

5. The formation of 'beef' has taken place during inversion of the Wessex Basin. 